\title{
Resource Use in Deep Litter Poultry System: Implications for Urban Food Security
}

\author{
Nsikak-Abasi A. Etim ${ }^{1}$, NseAbasi N. Etim², Jamal Mohammed ${ }^{3}$ \\ ${ }^{1}$ Department of Agricultural Economics \& Extension, \\ University of Uyo P.M.B 1017, Uyo, Akwa Ibom State, Nigeria. \\ Email:nsikakabasietim@uniuyo.edu.ng \\ ${ }^{2}$ Department of Animal Science, Akwa Ibom State University, Obio Akpa Campus, Akwa Ibom State, \\ Nigeria.Email: nseabasietim@gmail.com \\ ${ }^{3}$ Department of General/Liberal Studies, Faculty of Business and Management Studies, P.O. Box KF 981, \\ Koforidua Technical University, Koforidua, Ghana. \\ Email:jamalmobammed@ktktu.edu.gh \\ 2Correpondence:nsikakabasietim@minyo.edu.ng
}

Abstract

As urbanization increases, the locus of poverty is slowly shifting from rural to urban areas in what is known as urbanization of poverty. Thus, understanding how urban food system operate and finding ways to ensure that they remain sustainable is a mounting preoccupation. But urban livestock production has the potential to provide a significant contribution to the urban food security now and in the future and can lift the urban poor out of poverty. Information on resource use in deep litter poultry system is largely limited. Stochastic production frontier functions was used for data from deep litter poultry farmers to examine their efficiency technically, output orientation and level of farm. Farmers' consideration was through the multistage sampling procedure. Maximum likelihood based on estimation of parameters helped in the determination of efficiency. The study revealed that, land, water, medication, capital and labour. The result 0.76 mean efficiency suggests output from deep litter poultry production could be increased with available technology. Policies aimed at encouraging farmers to access productive resources would be sensible decision.

Keywords: Deep litter, food security, resource use, urbanization, Nigeria.

Citation: Etim, N. A., Etim, N. N. and Mohammed, J. Resource Use in Deep Litter Poultry System: Implications for Urban Food Security, 2020; 5(3): 38-44.

Received: April 4, 2020

Accepted: September 30, 2020 


\subsection{Introduction}

Globally, issues about food security has been topical and feature prominently within development policy indicators. A major driver of food insecurity is rapid population growth and urbanization.

Developing countries experience growth in an exponential rate particularly cities of underdeveloped nations. Shackleton et al., (2009) wrote that global urban population is projected to grow approximately 4.98 billion towards 2030. In Africa, Nigeria is acknowledged as a populated country and considered $7^{\text {th }}$ globally. UN (2017) reported Nigeria's population of 192 million, with a yearly growth rate of 2.5 percent and urban population of 50.2 percent.

A recent report by World Bank (2012) also makes an empirical comparison that urban population in Nigeria rises at approximately $4 \%$ per annum while rural population grows at approximately $1 \%$. Due to urbanization, the focus of poverty is gradually shifting to urban areas from the rural certain which is termed as urbanization of poverty. But urban livestock production has the potential to support urban food security and can lift the urban poor out of poverty. This particularly hinges on efficiency and the notion of productivity.

Efficiency of a firm is a term used to describe the firm's ability to obtain higher output with a given inputs. The study of Farrell (1957) became the first work on firm's efficiency and delineated into: allocative and technical efficiency. These two are gives rise to economic efficiency. Economic efficiency is defined as the process of producing an amount of output with minimum quantity of input. (Jondrow et al, 1982; Ali 1996). Earlier empirical study by Schmidt (1976) documented that measuring efficiency using deterministic models are disturbed by statistical noise. The preferred alternative is Stochastic Production Frontier Model. The Stochastic Production Frontier has an error term consisting synthetic and a one-sided component. The random effect is captured by the symmetric component which is normally distributed.

The Stochastic Frontier Production Function is of the form;

$Y_{i}=F\left(X_{i} ; \beta\right) \exp \left(V_{i}-U_{i}\right) i=1,2, ., N$

$Y_{i}$ is represents the $i^{\text {th }}$ firm's output; $X_{i}$ represents (MX2) vector of inputs; $\beta$ is the unknown parameter's vector which is estimated; $\mathrm{f}($.$) represents the appropriate form, V_{i}$ represent the symmetric error which is an exogenous shock and random effects; while $\mathrm{U}_{\mathrm{i}} \leq 0$ represents the sided error component.

The issue of urbanization, resource use and food insecurity are pressing global concern and subject of discourse among researchers and development stakeholders. Recently, there has been rapid migration of the rural poor to 
already swollen urban areas in search of better employment opportunities and improved livelihoods. Although some of the rural migrants have succeeded in finding better life, majority are unable to secure improved quality of life as their hopes have been dashed into a nightmare of hunger, poverty and food insecurity. Though, urbanization is seldom seen as a challenge too many development professionals and stakeholders, no nation has developed without urbanization and there is no developed nation that is not predominantly urban. Whereas urbanization as driver of economic growth and development brings a positive development, nonetheless, it has outstretched the capacities of most cities to absorb and manage the growing population. This low absorptive capacity of the cities has led to the development of slums and posed considerable threat to all dimensions of food security.

This rural-urban drift has also resulted in declining farmland, rising food prices, pressure on land resource and livelihood of vast majority of the urban poor. Population pressure together with increasing urbanization has considerably reduced the land available for meaningful agricultural production. Currently, livestock is among the most valuable agricultural sub-sectors within Nigeria as such provide significant share to agricultural Gross Domestic Product. This gross domestic product of Nigeria is largely influenced by livestock products influenced in demand pattern by the population. On the other hand, the supply of livestock is rapidly affected by competition for limited natural resources. But, livestock is one of the key priority sub-sectors that can contribute to economic growth, poverty reduction and food security. However, resource poor farmers play an important part for food production and security yet they have to cope with numerous challenges including inefficient management and over-use of resources.

Like any other agricultural production, deep litter poultry production requires the use of resources. But to optimize production and ensure food security, resources must be managed and utilized as efficiently as possible. Using appropriate technology and the right resource mix, deep litter poultry producers can engineer a sustainable urban livestock revolution. An empirical study was therefore conducted in Akwa Ibom State, Niger Delta region of Nigeria to determine the resources use efficiency in deep litter poultry production system.

Empirically, Omondi (2018) opined in their study that urban chicken producers contribute to income generation and the food chain production. This invariably reduces food security. In addition, Oluwafemi et al., (2014) studied production efficiency of battery cage and deep litter systems and made comparison between the two. Their results found the battery cage farmers to be more economically efficient as compared with the deep litter systems. 
The issue about efficiency has subtly being underscored by practicing poultry farmers and thus, it is essential regarding food security. The rest of the sections of the paper deals with the methodology, results and discussions, conclusions and recommendations.

\subsection{Methodology}

The study centered in Akwa Ibom State of Nigeria. The state has (6) Agricultural Development (ADP) zone. It has two season namely the short dry and rainy season. The annual precipitation ranges between $2000-3000$ $\mathrm{mm}$ per annum. This rainfall regime witnessed in major parts of the state support farming throughout the year (Etim and Ofem, 2005; Etim and Udoh, 2014).

To estimate technical efficiency of deep litter poultry producers, the stochastic frontier production function model was considered. Using the multistage sampling procedure, one hundred and twenty (120) representative small holder farmers were selected. Primary data were obtained with the help of well-structured and unstructured questionnaire. Asymptotic parameter estimates were evaluated to describe the explainers of efficiency of resource use by poultry producers.

\section{Model Specification}

The stochastic production frontier which incorporates hypothesized efficiency (Coelli and Battese, 1996; Etim and Udoh, 2014) was used for the study. The production functional form is specified as follow:

$$
\begin{aligned}
& \operatorname{Ln}(\text { Qty })=\beta_{0}+\beta_{\mathrm{i}} \operatorname{Ln}(\operatorname{Land})+\beta_{2} \operatorname{Ln}(\text { water })+\beta_{3} \operatorname{Ln} \text { (medication) } \\
& +\beta_{4} \operatorname{Ln}(\text { capital })+\beta_{5} \operatorname{Ln}(\text { labour })+V_{i}-U_{i}--(1)
\end{aligned}
$$

Where Qty represents poultry product in naira; land is size of poultry; water is the quantity of water measured in litres; medication refers drugs value in naira; capital refers depreciation estimated on the farm implements valued in naira; labour employed in farm operation in mandays.

With $\mathrm{V}_{\mathrm{i}} \sim \mathrm{N}\left(\mathrm{O}, \mathrm{V}^{2}\right)$ and

$\delta^{- \text {ui }}=\delta_{0}+\delta_{1}($ Sex $)+($ Age $)+\delta_{3}($ Credit $)+\delta_{4}(\mathrm{Mkt})+\delta_{5}(\mathrm{HHS})+\mathrm{Z}_{\mathrm{i}---}(2)$

Where sex is sex of the farmer (dummy); Age represents farmer's age in (years); Credit presents availability of credit (dummy); Mkt is access to market (dummy). HHS is the number of family members; $Z_{\mathrm{i}}$ is an error term. The equations were estimated by maximizing the likelihood function (Yao and Liu, 1998; Etim and Udoh, 2014).

\subsection{Results and Discussions}

Descriptive Statistics: The findings are summarised in Table 1. The findings revealed that average farm size for poultry on small farms resulted in $100 \mathrm{~m}^{2}$. This could be because of the labor-intensiveness of poultry production or because the farmers were incapable of acquiring larger holdings. 
Table 1: Summary Statistics of the Poultry Farm

\begin{tabular}{cccc}
\hline Descriptive & Units & Mean & Range \\
\hline Output & Naira ( $)$ & 3500 & $1500-8000$ \\
Land & Square meter & 100 & $50-180$ \\
Water & Litres & 500 & $250-1000$ \\
Medication & Naira ( & 1200 & $1800-4000$ \\
Capital & Naira ( & 3800 & $5000-18000$ \\
Labour & Mandays & 120 & $40-500$ \\
Age & Years & 40 & $28-63$ \\
Household size & Number & 4 & $2-9$ \\
\hline
\end{tabular}

* Naira (N)

The statistics on age shows that the farmers were in the productive age category.

Results on Maximum Likelihood: The maximum likelihood estimates and inefficiency determinants are presented in Table 2 . The sigma square $(0.7836)$ is significant $(\mathrm{p}<0.05)$ and different from zero indicate goodness of fit.

Result revealed that the variance ratio defined as $\lambda=\left(\sigma \mathrm{u}^{2} / \sigma \mathrm{u}^{2}+\sigma \mathrm{u}^{2}\right)$ which was 73.00 percent indicate the presence of technical inefficiency among poultry producers explained about 73.00 percent variation in the poultry output. This confirms one-sided error component suggesting the shortcoming of the ordinary least square estimation technique.

Results of analysis also showed an average technical efficiency of $0.76(76 \%)$ allowing a gap of $0.24(24 \%)$ portraying that about $24 \%$ increased poultry production could be obtained with well managed resources and appropriate input mix. Furthermore, it is revealed that the most critical resources in poultry production that would reduce poverty among farmers if utilized efficiently were land elasticity 0.6140 , followed by labor elasticity 0.4704 , capital medication with elasticity of 0.3360 , capital with elasticity of 0.3166 and water with elasticity of 0.2118. In this study, land is significant and positively signed implying that increasing the size of holdings increases the opportunity of resource utilization thus leading to increased technical efficiency and food security. Labour is the second highly important product resource elasticity 0.4704 . The relative large coefficient for labour is an indication that deep litter poultry production is highly labour intensive and impacts positively on efficiency of resource use and food security. Similar empirical results were obtained by Etim and Udoh, 2014; Etim et al (2014); Etim 2014.

The Credit was positive. Results implies that accessibility to credit facilities to farmers tends to eliminate the production barriers hence making it easier for prompt purchase of resources thereby raising productivity and food security via efficiency. Result corroborate with earlier empirical findings by Mohammed (2009); Aye and 
Mungatana (2010), Etim et al (2013) and Etim and Udoh (2014). Access to agricultural credit to farmers is an salient variable and has a positive relation but it has eluded farmers in Nigeria (Philip, 2009; Etim and Udoh, 2014).

Age, access to credit, household size were the most important explainers of inefficiency of resource use. From the findings, none of the livestock farmers in the region reached the frontier threshold as they were technically inefficient in resource use. The efficiency indices across livestock farms reveal a varied picture as the technical efficiency of all the sampled farms was less than one. This means that no poultry farm reached the limit verge. The mean technical efficiency index of 0.76 implies there allow space for enhancing output using available technology and right resource mix.

Table 2: Maximum Likelihood Estimates and Inefficiency Function

\begin{tabular}{lcc}
\hline \multicolumn{1}{c}{ Variable } & Coefficient & Asymptotic t-value \\
\hline Production Function & 0.0355 & \\
Constant term & 0.614 & 0.4459 \\
Land $\left(\beta_{1}\right)$ & 0.2118 & $2.1107^{* *}$ \\
Water $\left(\beta_{2}\right)$ & 0.3360 & $1.9965^{*}$ \\
Medication $\left(\beta_{3}\right)$ & 0.3166 & $3.0766^{* * *}$ \\
Capital $\left(\beta_{4}\right)$ & 0.4704 & $2.3302^{* *}$ \\
Labour $\left(\beta_{5}\right)$ & & $4.8433^{* * *}$ \\
Explainers of Inefficiency & 0.0831 & \\
Intercept $\left(\delta_{0}\right)$ & 0.2099 & $1.9810^{*}$ \\
Age $\left(\delta_{1}\right)$ & 0.4311 & $2.1069^{* *}$ \\
Sex $\left(\delta_{2}\right)$ & 0.1189 & 1.2310 \\
Credit $\left(\delta_{3}\right)$ & 0.3357 & $3.1708^{* * *}$ \\
Market $\left(\delta_{4}\right)$ & 0.5069 & 1.067 \\
Household size $\left(\delta_{5}\right)$ & & $2.9713^{* * *}$ \\
Diagnostic Statistics & 0.7836 & \\
Sigma-square $\left(\delta s^{2}\right)$ & 0.7300 & $2.8155^{* *}$ \\
Gamma $(\lambda)$ & 14.0695 & $1.8007^{*}$ \\
Ln $(L i k e l i h o o d)$ & 8.2601 & \\
LR Test & 1.5021 & \\
Quasi function & 120 & \\
Number of observations & & \\
\hline
\end{tabular}

Note: $* * *, * *$ and $*$ indicate significance at $1 \%, 5 \%$ and $10 \%$ respectively 


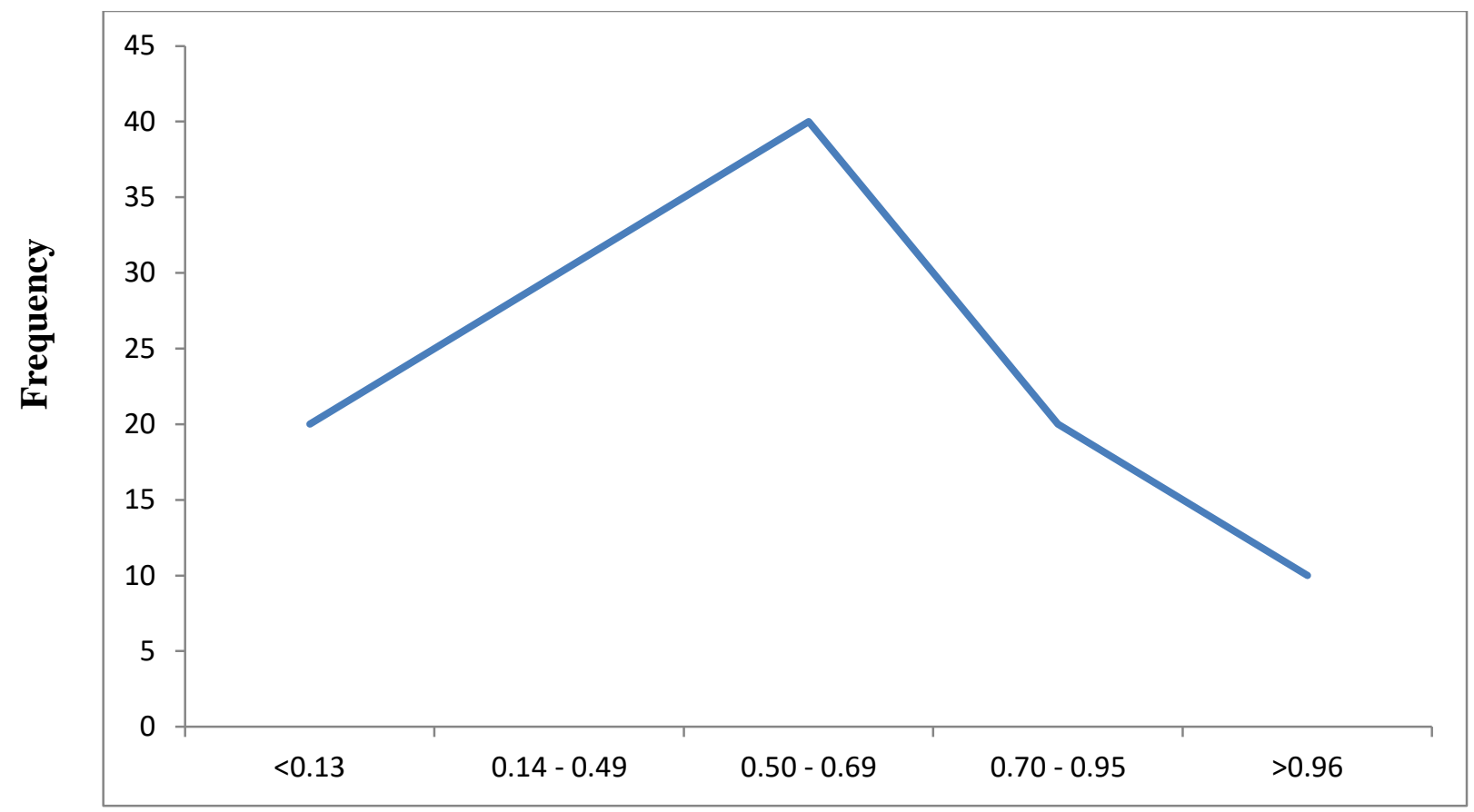

Efficiency Class

Mean Efficiency $=0.76$ Minimum $=0.03$ Maximum $=0.96$

\subsection{Conclusion and Recommendation}

To attain economies of scale and output expansion, urban livestock farmers should increase their stocking density either by land consolidation or acquiring new farm plots. Promoting efficient resource use aimed at increasing food production and income is a sensible policy option that will likely ensure food security and achieve sustainable development goals by 2030 .

The study recommended that there should be some provision of Policies to stimulate farmers' access productive resources. Such could help the fight towards food insecurity in Nigeria. 


\section{References}

Ali, M. (1996). Quantifying the socio-economic determinants of sustainable crop production: An application to wheat cultivation in the Tarui of Nepal, Agricultural Economics 14:45-60.

Aye, G. C. and Mungatana, E. D. (2010). Technical Efficiency of Traditional and Hybrid maize farmers in Nigeria: Comparison of alternative approaches. African Journal of Agricultural Research 5(21): 29092917.

Coelli, J. T. and Battese, G. (1996). Identification of factors that influence the Technical inefficiency of Indian Farmers. Australian Journal of Agricultural Economics 40(2): 103-128.

Coelli, T. J. (1995). Recent Development in Frontier Modeling and Efficiency Measurement. Australian Journal of Agricultural Economics 39, 219-45.

Etim, N. A. (2014). Are Small Scale Egg Plant Producers Efficient in Resource Use? American Journal of Agriculture and Forestry 2(4): 154-158.

Etim, N. A. and E. J. Udoh (2014). Identifying Sources of Efficiency among Resource Poor Agricultural Economics 2(1): 33-39.

Etim, N. A. and Ofem, B. (2005). Urban farming and Household Waste Management in Uyo Urban. Implications for Environmental Harmony. Nigerian Journal of Food and Environments 2(2): 74-80.

Etim, N. A., Etim, N. N. and E. E. A. Offiong (2014) Estimation of Efficiency in Small Scale Pig Production. European International Journal of Science and Technology 3(6): 111-118.

Etim, N. A., Thompson D. and Onyenweaku, C. E. (2013). Measuring Efficiency of Yam (Dioscorea spp) Production among Resource Poor Farmers in Rural Nigeria. Journal of Agricultural and Food Sciences $1(3): 42-47$.

Farrel, M. (1957). The measurement of productive efficiency, journal of Royal Statistical Society, ACXX Part 3:253-90.

Forsund, F. R., C.A.K. Lovell and P. Schmidt (1980). A survey of frontier production functions and their relationships to efficiency measurement. Journal of econometrics 13:5-25.

Jondrow, J. C.A., L. S. Lovell and P. S. Schmidt (1982). On the Estimation of Technical Inefficiency in the Stochastic Frontier Production Function Model. Journal of Econometrics 19:233-8.

Kalaitzandonakes, N. G., W. Shua Xiang and M. Jianahun (1992). Relationship between Technical Efficiency and Farm size revisited, Canadian Journal of Agricultural Economics, 40:427-42.

Mohammed, S. T., Glide, A. A., Shettima, B. G. and Umorun, M. Y. (2014). Resource - Use efficiency of Male and Female Fish Farmers in Maiduguri: A Comparative Analysis. Nigerian Journal of Fisheries and Aqua Culture 2(1): 6-14.

Oluwafemi John Aladejebi, Luke O Okojie, and Carolyn Afolake Afolami (2014). Comparative Production Efficiency of Battery Cage and Deep Litter System in the Drive towards Sustainable Poultry Egg Farming in Ogun State, Nigeria. Journal of Sustainable Development in Africa (Volume 16, No.4, 2014) ISSN: $1520-5509$

Omondi, S.O. (2018). Economic analysis of small-scale poultry production in Kenyan medium-sized cities of Kisumu and Thika. 30th International Conference of Agricultural Economists. Vancouver.

Philip, D. Nkonya, E., Pender, J. and Oni, O. A. (2009). Constraints to Increasing Agricultural Productivity in Nigeria: A Review. Nigeria Strategy Support Programme Paper No. NSSP 006. International Food Policy Research Institute.

Schmidt, P. (1976). On the Statistical Estimation of Parametric Frontier Production Functions: The Review of Economics and Statistics, 58:238-239.

Shackleton, C.M., Pasquini, M.W and Drescher,A.W (2009) Eds. African Indigenous Vegetables in Urban Agriculture. Earthscan. London. Sterling, VA.

UN (United Nations) 2017. World Domestics. Department of Economic and Social Affairs. Population Division. World Population Prospects. The 2017 Revision.

World Bank (2012). World Bank Indicator. Nigeria-Density and Urbanization. World Bank Report. 